\title{
Orthodoxy and Philosophy
}

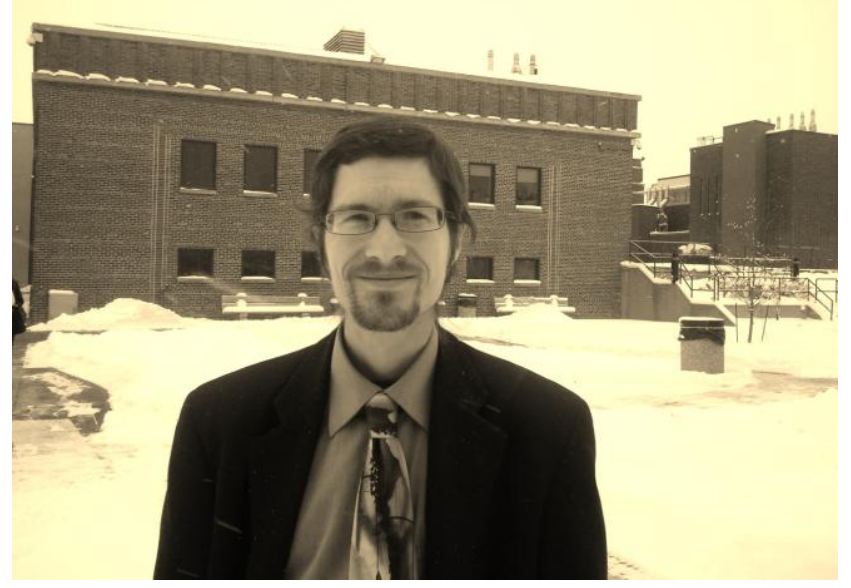

Travis Dumsday received his doctorate in philosophy in 2010 from the University of Calgary. After a postdoctoral fellowship at the University of North Carolina Chapel Hill, he taught for a year at Livingstone College and then in 2012 took up a post at Concordia University of Edmonton. A convert to Orthodoxy from Presbyterianism (chrismated in 2009), Dumsday works in multiple areas of philosophy, including philosophy of science, metaphysics, philosophy of religion, and bioethics.

Tudor Petcu: With your permission, I would like to focus first of all on the idea of "Orthodox philosophy", which in my opinion is so important, for at least three reasons: the rebirth of Orthodoxy in the secular and postmodern society; a right-minded understanding of the Orthodox civilisation; and of course the cultural importance of Orthodoxy even for the Western societies, which societies are based mainly on Catholic or Protestant identities. Talking about any orthodox philosophy could be something challenging and difficult but it is a moral duty for us to highlight the philosophical tasks of Orthodoxy. From this point of view I would like to ask you if you consider that the main characteristic of Orthodoxy could be metaphysics. And when I am saying "metaphysics" I especially make reference to the works of Holy Fathers of the Church such as Saint Maximus the Confessor.

Travis Dumsday: The issue of the relationship between Orthodoxy and philosophy is of course very old and very complicated. It is well-known that the dialogue with Greek philosophy (Aristotle, Plato, the Stoics, the neo-Platonists etc.) had an important set of roles to play in Church history, from the apostolic era onwards. These included roles in the understanding of Church dogma (e.g., the use of concepts like 'substance' and 'essence' in discussions at the early Ecumenical Councils) and in the defence of that dogma.

These facts apply historically to all of the main sub-disciplines of philosophy, including: ethics (the study of morality); epistemology (the study of knowledge and of related concepts like evidence and rationality); and, as you rightly note, metaphysics (the study of the nature and existence of things). In each case, the Holy Fathers made considerable use of Greek philosophical ideas. 
That having been said, one of the interesting features of the relationship specifically between Orthodoxy and philosophy is the great diversity apparent in the Tradition. Orthodox thinkers have been influenced by a variety of philosophical schools (again, Aristotelian, neo-Platonic etc.), and there is no one philosophical school which could be considered as the official philosophy of the Orthodox Church. This internal diversity distinguishes Orthodoxy somewhat from Roman Catholicism, which has historically tended to treat Thomism as a sort of semi-official philosophical system.

Tudor Petcu: We know very well the evolution and the foundations of contemporary American philosophical approaches and, if I'm not wrong, I think by the American philosophy we may understand first of all analytic philosophy defined especially by the philosophy of language and different theories in logics which are, of course, essential for our philosophical background. I would also take into account the contemporary American political philosophy influenced especially by the idea of global justice, well-known because of Thomas Pogge. Given all I have mentioned above, what would be the place of Orthodox philosophy among these American philosophical approaches?

Travis Dumsday: It's certainly true that in the English-speaking world, the analytic approach remains the dominant way of doing philosophy. Being an analytic philosopher myself, I'm glad! Moreover, I think that Orthodox theology fits very nicely into analytic modes of thought. Analytic philosophy is characterized in part by its great emphasis on logic and clarity of argumentation. This focus on clear argument is absolutely evident in many of the Holy Fathers. Look for instance at some of the arguments employed by St. Athanasius or St. John of Damascus; indeed, just look at the overall structure of their major works. They are clearly organized and logically structured. So I think there is a natural sympathy between analytic philosophy and Orthodoxy.

That having been said, there are of course other major traditions in contemporary philosophy besides the analytic, and Orthodox thinkers cannot afford to ignore them. I think for instance of the continental, pragmatist, and Scholastic traditions. These too can be productive dialogue partners with Orthodox thought (in particular the Scholastic tradition).

I'm afraid I'm very poorly read in American political philosophy, so won't try to say anything about Prof. Pogge!

Tudor Petcu: I would be very interested to find out how you understand orthodox spirituality in North America, particularly in Canada, with its own heritage, traditions and particularities. Let's talk about for example the contributions of John Meyendorff to the evolution of American Orthodoxy and its scholarship. I wouldn't forget Seraphim Rose too, who is deeply appreciated especially in the Eastern Europe. So, tell me please: how would you characterise American Orthodoxy?

Travis Dumsday: God always works to bring good out of evil, and a wonderful example of this providential work can be found in the intellectual tradition sparked by the Russian diaspora. After the communist revolution of 1917, many important Orthodox intellectuals left for Paris and other major centres of scholarship, including, eventually, centres in North America. Many of the most important North American Orthodox scholars are the products of this diaspora, even if second-generation.

Of course, Orthodoxy was present in North America even before the communist takeover in Russia, as evidenced (for example) by the inspiring history of Orthodox missionaries in Alaska. And, living as I do in Alberta, I must mention too the huge waves of Ukrainian immigration to western Canada 
beginning in the late $19^{\text {th }}$ century. That pre-revolutionary diaspora has also bequeathed a remarkable Orthodox heritage to Canada.

I am pleased to hear that Fr. Seraphim is being widely read in Eastern Europe. I have certainly benefitted from his writings (though I do disagree with some of his ideas, for instance his views on creationism).

Tudor Petcu: What does it mean for you to be an Orthodox Christian? And what does it mean for you to be an Orthodox philosopher in Canada?

Travis Dumsday: To be an Orthodox Christian is, in part, to have the amazing privileges of (a) access to the fullness of truth and (b) access to valid sacraments. Other Christian bodies do of course teach a great deal of the truth, but it is mixed in with error. And while other Christian bodies do have some valid sacraments (notably baptism), only in the Orthodox Church can we confidently partake of the genuine body and blood of Christ in the eucharist.

I love the philosophical scene in Canada; we have an energetic philosophical community and a variety of philosophical associations that actively hold conferences etc.

On being an Orthodox philosopher in Canada, I do try to bring my faith to bear on at least some of my philosophical work. In fact I'm very fortunate to be teaching at an institution (Concordia University of Edmonton) which encourages the pursuit of distinctly Christian scholarship.

Tudor Petcu: One of the deepest spiritual ideas which impressed me much and influenced my thinking remains, and always will, "the hidden holiness", idea which belongs to Michael Plekon. I would like you to tell me: how do you understand the hidden holiness from your own orthodox perspective?

Travis Dumsday: To my discredit, I'm not very familiar with the works of Plekon.

Tudor Petcu: Which would be in your opinion the most important role of Orthodoxy in the postmodern and pragmatic world? Could there exist any common denominator between Orthodoxy and pragmatism?

Travis Dumsday: I think it would depend on the particular version of pragmatism under discussion. Personally I am sceptical of many ideas coming out of pragmatist schools of thought, but some versions are friendlier to Orthodoxy than others. For instance, the works of C.S. Peirce are (in large part) broadly compatible with many Orthodox ideas. By contrast, someone like Richard Rorty is very much antithetical to Christian ways of thinking. Something similar could be said of postmodernism; there are certain strands of thought in postmodernism that are compatible with Christianity and can even provide new insights to Christian thinkers (a point emphasized by the American philosopher James K.A. Smith), but much of it seems to me deeply problematic.

Tudor Petcu: Given your entire Orthodox experience, and I would say way of living, what is the most relevant and the deepest idea that we can find in Orthodox spirituality and theology? Would it be correct to say that Orthodoxy represents the highest and the deepest way of living?

Travis Dumsday: I think the deepest idea we can find in Orthodox theology is in fact the deepest idea we can find in Christianity generally: God loves us so much that He sent his only-begotten Son to die 
for us. That is absolutely mind-blowing, and if a person really believes it, it will have a profound impact on every area of his or her life.

Tudor Petcu: If you should recommend one book, just one book, to someone who wants to better understand Orthodox spirituality, which would it be?

Travis Dumsday: Tough question! I'm not really sure; however, I am fond of Metropolitan Anthony Bloom's little book titled Living Prayer. That's certainly a good place to start. 